\section{Schiffnerulaceous fungi of Kodagu, Karnataka, India}

\section{V.B. Hosagoudar ${ }^{1}$, C. Jagath Thimmaiah $^{2}$ \& M. Jayashankara ${ }^{3}$}

${ }^{1}$ Tropical Botanic Garden and Research Institute, Palode, Thiruvananthapuram, Kerala 695562, India

2,3 Department of Studies and Research in Microbiology, Mangalore University Post Graduate Centre, Cauvery Campus, Madikeri, Kodagu, Karnataka 571201, India

Email: ${ }^{1}$ vbhosagoudar@rediffmail.com (corresponding author),

2 jgtct@rediffmail.com, ${ }^{3}$ jaishankara@yahoo.com

The genus Schiffnerula represents four synanamrophs: Mitteriella, Questieriella, Sarcinella, Digitosarcinella and their teleomorph, Schiffnerula. This genus has been revised for India (Hosagoudar 2011). During the study of foliicolous fungi of Kodagu, we could study several collections belonging to this genus and of which the following four taxa turned as new to science and are described and illustrated here.

\section{Questieriella ophiorrhizae sp. nov.} (Image 1)

Material examined: 21.xi.2009, on leaves of Ophiorrhiza sp. (Rubiaceae), in the campus of Bharatiya Vidyabhavan Kodagu Vidyalaya, Madikeri, Kodagu, Karnataka, C. Jagath Thimmaiah, TBGT 5706 (holotype), (MycoBank 564009).

Coloniae epiphyllae, tenues, velutinae, ad $3 \mathrm{~mm}$ diam., confluentes. Hyphae rectae vel flexuosae, alternatae, oppositae vel irregulariter acuteque vel laxe

Date of publication (online): 26 December 2011

Date of publication (print): 26 December 2011

ISSN 0974-7907 (online) | 0974-7893 (print)

Editor: R.K. Verma

Manuscript details:

Ms \# 02988

Received 02 November 2011

Finally accepted 22 November 2011

Citation: Hosagoudar, V.B., C.J. Thimmaiah \& M. Jayashankara (2011) Schiffnerulaceous fungi of Kodagu, Karnataka, India. Journal of Threatened Taxa 3(12): 2268-2271.

Copyright: ( V.B. Hosagoudar, C. Jagath Thimmaiah \& M. Jayashankara 2011. Creative Commons Attribution 3.0 Unported License. JoTT allows unrestricted use of this article in any medium for non-profit purposes, reproduction and distribution by providing adequate credit to the authors and the source of publication.

\section{OPEN ACCESS | FREE DOWNLOAD}

ramosae, laxe reticulatae, cellulae 12-19 x 5-7 $\mu \mathrm{m}$. Conidiophorae producentes hyphis lateralis,

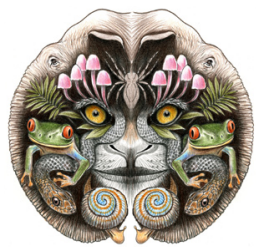
simplices, micronematae, macronematae, 0-2-septatae, simplices, raro ramosae, 15-18 × 6-8 $\mu \mathrm{m}$; cellulae conidiogenae terminalis, integratae, ovalis vel cylindraceae; conidia solitaris, simplices, sicca, ellipsoidea, fusiformes, falcata, sigmoidea, pallide brunnea, 3-septata, cellulae terminalis acutae ad apicem, 38-45 x 9-11 $\mu \mathrm{m}$.

Colonies epiphyllous, thin, velvety, up to $3 \mathrm{~mm}$ in diameter, confluent. Hyphae straight to flexuous, branching alternate, opposite to irregular at acute to wide angles, loosely reticulate, cells $12-19$ x 5-7 $\mu \mathrm{m}$. Conidiophores produced lateral to the hyphae, simple, micronematous, macronematous, 0-2-septate, simple, rarely branched, 15-18 x 6-8 $\mu \mathrm{m}$; conidiogenous cells terminal, integrated, oval to cylindrical; conidia solitary, simple, dry, ellipsoidal, fusiform, falcate, sigmoid, pale brown, 3-septate, terminal cells acute at the tip, 38-45 x 9-11 $\mu \mathrm{m}$.

Schiffnerula craterispermi (Hansf.) Hughes, S. hendrickxii (Hansf.) Hughes, S. psychotriae

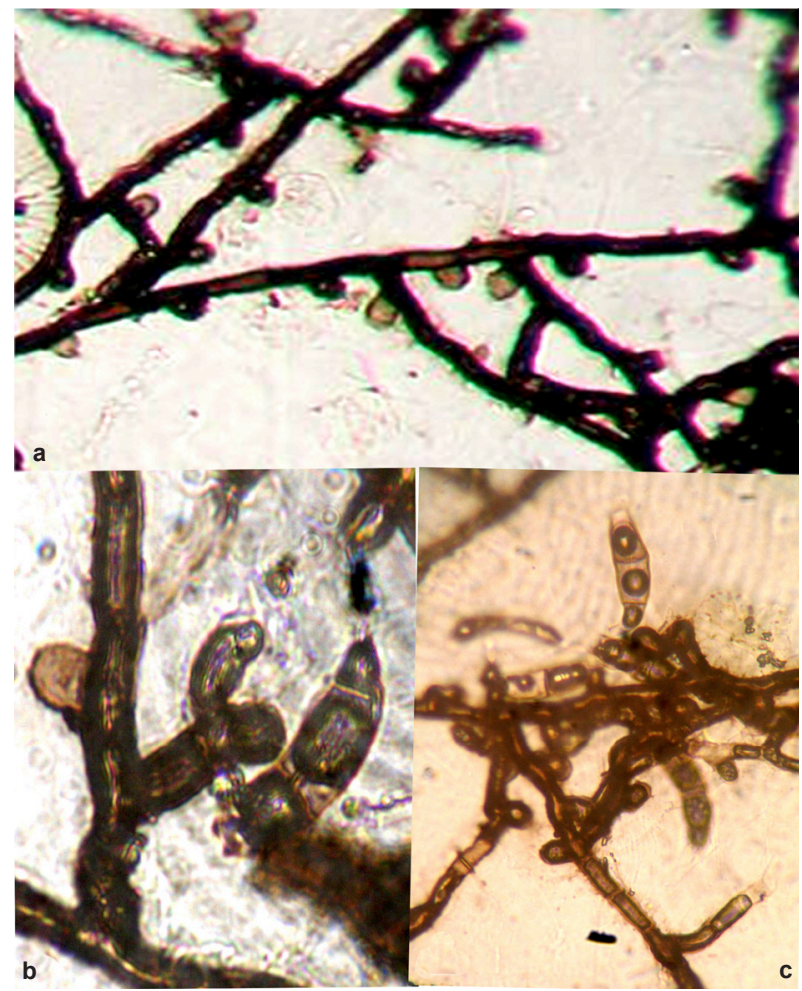

Image 1. Questieriella ophiorhizae sp. nov.

a - Appressoriate mycelium; b-c - Conidiophore and conidia 
(Doidge) Hughes, S. palicoureae (Farr) Hughes, $S$. ugandensis (Hansf.) Hughes are known from other parts of the country (Hosagoudar 2003). From India, Schiffnerula canthii Hosag. \& Archana on Canthium sp. and Schiffnerula braunii Hosag. \& Sabeena on Morinda spp. are known on the members of the family Rubiaceae (Hosagoudar \& Sabeena 2010). All these species are in their teleomorphs but the present fungus persists only in its Questieriella form. Hence, it has been accommodated in a new species.

Etyomology: Based on the host genus

\section{Sarcinella caralliae sp. nov.} (Image 2)

Material examined: 01.xi.2009, on leaves of Carallia brachiata (Lour.) Merr. (Rhizophoraceae), Kaimada field, Hoddur, Kodagu, Karnataka, C. Jagath Thimmaiah TBGT 5708 (holotype), (MycoBank 564010).

Coloniae amphigenae, plerumque epiphyllae, tenues vel densae, patentiae, ad $3 \mathrm{~mm}$ diam. Hyphae rectae vel flexuosae, pallide brunnae, irregulariter acuteque vel laxe ramosae, laxe reticulatae, cellulae $12-20 \times 4-6 \mu \mathrm{m}$. Appressoria dispersa, alternata, unilateralis, ovata vel plerumque globosa, integra, $8-10 \times 6-8 \mu \mathrm{m}$. Conidiophorae producentes hyphis lateralis, simplices, micronematae, $6-8 \mu \mathrm{m}$ longae; cellulae conidiogenae terminalis vel intercalaris, monoblasticae, integratae, determinatae, cylindraceae. Conidia solitaris, sicca, simplices, subspherica vel ovalis, 2-10-cellulae, brunnea vel nigra, muriformes,

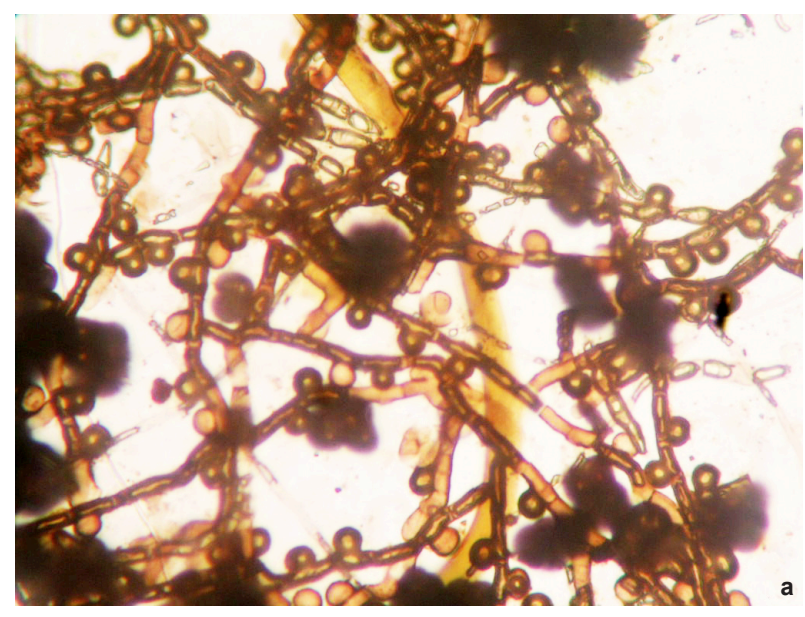

Image 2. Sarcinella caralliae sp. nov. a - Appressoriate mycelium with sarciniform conidia sarcinatim septatis, constrictus ad septatis, $21-30 \mu \mathrm{m}$ diam., parietus glabrus.

Colonies amphigenous, mostly epiphyllous, thin to dense, spreading, up to $3 \mathrm{~mm}$ in diameter. Hyphae straight to flexuous, pale brown, branching irregular at acute to wide angles, loosely reticulate, cells 12-20 × 4-6 $\mu \mathrm{m}$. Appressoria scattered, alternate, unilateral, ovate to mostly globose, entire, $8-10 \times 6-8$ $\mu \mathrm{m}$. Conidiophores produced lateral to the hyphae, simple, micronematous, $6-8 \mu \mathrm{m}$ long; conidiogenous cells terminal, intercalary, monoblastic, integrated, determinate, cylindrical. Conidia solitary, dry, simple, subspherical to oval, 2-10-celled, brown to charcoal black, muriform, sarcinately septate, constricted at the septa, $21-30 \mu \mathrm{m}$ in diameter, wall smooth.

This is the first species of schiffnerulaceous fungus infected the members of the family Rhizophoraceae (Hosagoudar 2003, 2011).

Etyomology: Based on the host genus.

\section{Schiffnerula aristolochiae sp. nov. (Image 3)}

Material examined: 04.xii.2009, on leaves of Aristolochia tagala Cham. (Aristolochiaceae), Devara kadu, Hoddur, Kodagu, Karnataka, C. Jagath Thimmaiah TBGT 5703 (holotype), (MycoBank 564011).

Coloniae epiphyllae, subdensae vel densae, ad 2 $\mathrm{mm}$ diam., confluentes. Hyphae rectae vel subrectae, alternatae vel oppositae acuteque vel laxe ramosae, laxe reticulatae, cellulae $16-20$ x 5-8 $\mu \mathrm{m}$. Appressoria unilateralis, alternata vel raro opposita, ovata, globosa, mammiformes, crassa posita, integra, $10-15$ x 7-10 $\mu \mathrm{m}$. Conidiophorae Questieriella producentes hyphis lateralis, simplices, rectae, micronematae, mononematae, 0-2-septatae, 20-25 x 4-6 $\mu \mathrm{m}$; cellulae conidiogenae terminalis, monoblasticae, integratae, solitaris, ellipsoidaleae; conidia recta vel curvula, pallide brunnea, 3-septata, plerumque in coloniis dispersa, 20-25 x 4-6 $\mu \mathrm{m}$. Thyriothecia numera, orbicularis, portionio ad centralis dissolutus, portionio marginalis intactus et radiatus, ad $50 \mu \mathrm{m}$ diam.; asci ovalis, globosi, octospori, ad $20 \mu \mathrm{m}$ diam.; ascosporae conglobatae, brunneae, uniseptatae, plus minus constrictus ad septatus, $25-30 \times 12-15 \mu \mathrm{m}$.

Colonies epiphyllous, subdense to dense, up to $2 \mathrm{~mm}$ in diameter, confluent. Hyphae straight to 

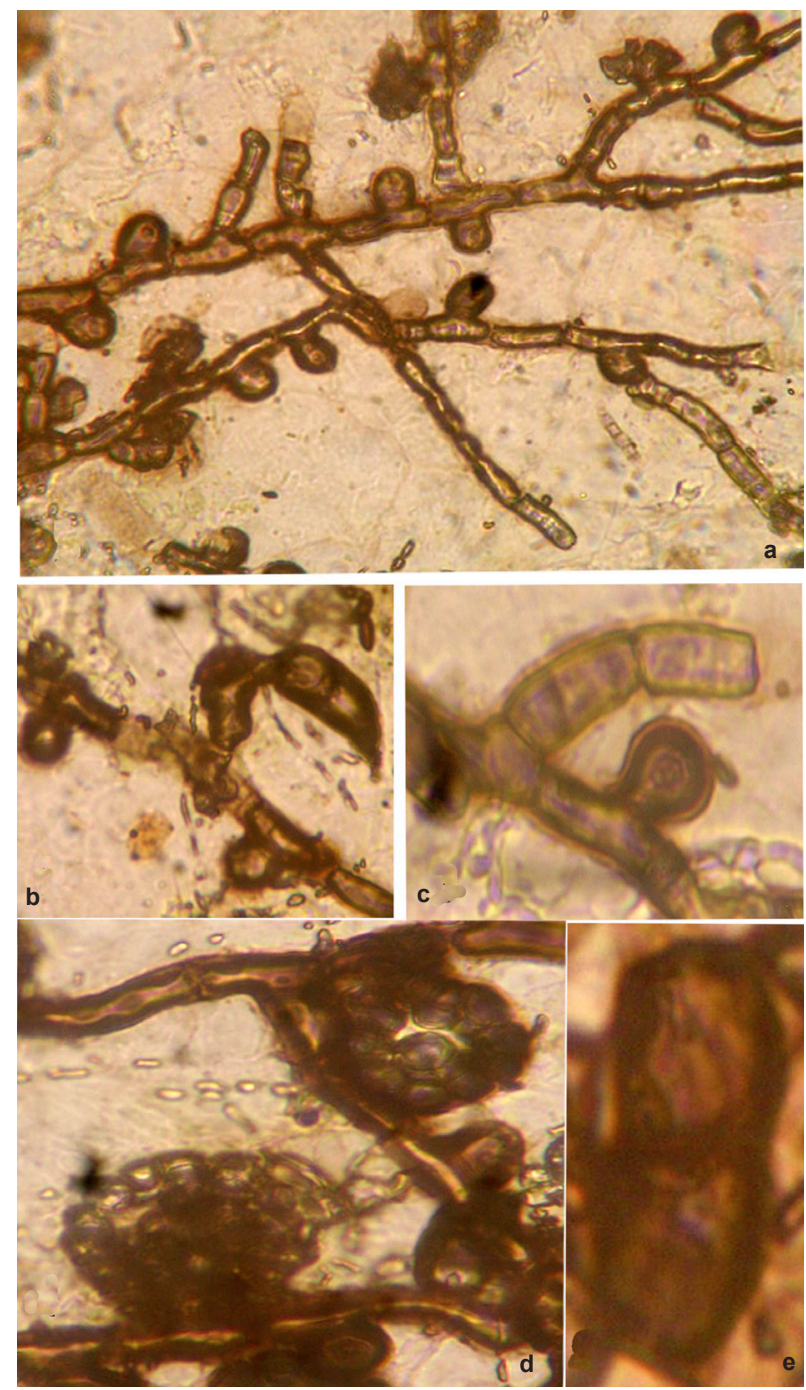

Image 3. Schiffnerula aristolochiae sp. nov.

a - Appressoriate mycelium; b - Questieriella conidia on conidiophores; c - Conidiophore; d - Thyriothecia; e - Ascospore

substraight, branching alternate to opposite at acute to wide angles, loosely reticulate, cells $16-20$ x 5-8 $\mu \mathrm{m}$. Appressoria unilateral, alternate to rarely opposite, ovate, globose, mammiform, broad based, entire, 10-15 x 7-10 $\mu \mathrm{m}$. Conidiophores of Questieriella produced lateral to the hyphae, simple, straight, micronematous, mononematous, 0-2-septate, 20-25 x 4-6 $\mu \mathrm{m}$; conidiogenous cells terminal, monoblastic, integrated, solitary, ellipsoidal; conidia straight to curved, pale brown, 3-septate, mostly scattered in the colonies, 20-25 x 4-6 $\mu \mathrm{m}$. Thyriothecia numerous, orbicular, central portion dissolved by exposing asci but the marginal cells remain intact and radiating, up to $50 \mu \mathrm{m}$ in diameter; asci oval, globose, octosporous, up to $20 \mu \mathrm{m}$ in diameter; ascospores conglobate, brown, uniseptate, more or less constricted at the septum, 25$30 \times 12-15 \mu \mathrm{m}$.

The conidia of Questieriella were scattered in the colonies, initially produced spores were intact and formed colonies. In case of subsequently produced spores, terminal cells were disintegrated; middle cells were deep brown, appressoria and mycelium produced from the central cells.

This forms the first report of the genus Schiffnerula on the members of Aristolochiaceae (Hosagoudar, 2003, 2011).

Etyomology: Based on the host genus.

\section{Schiffnerula hoddurensis sp. nov.} (Image 4)

Material examined: 16.xi.2009, on leaves of Vitex negundo L. (Vitaceae), Hoddur, Kodagu, Karnataka, C. Jagath Thimmaiah TBGT 5698 (holotype), (MycoBank 564012).

Coloniae epiphyllae, densae, ad $7 \mathrm{~mm}$ diam. Hyphae flexuosae, suboppositae vel alternatae acuteque vel subacuteque ramosae, arte vel laxe reticulatae, cellulae 23-28 x 4-6 $\mu \mathrm{m}$. Appressoria dispersa,

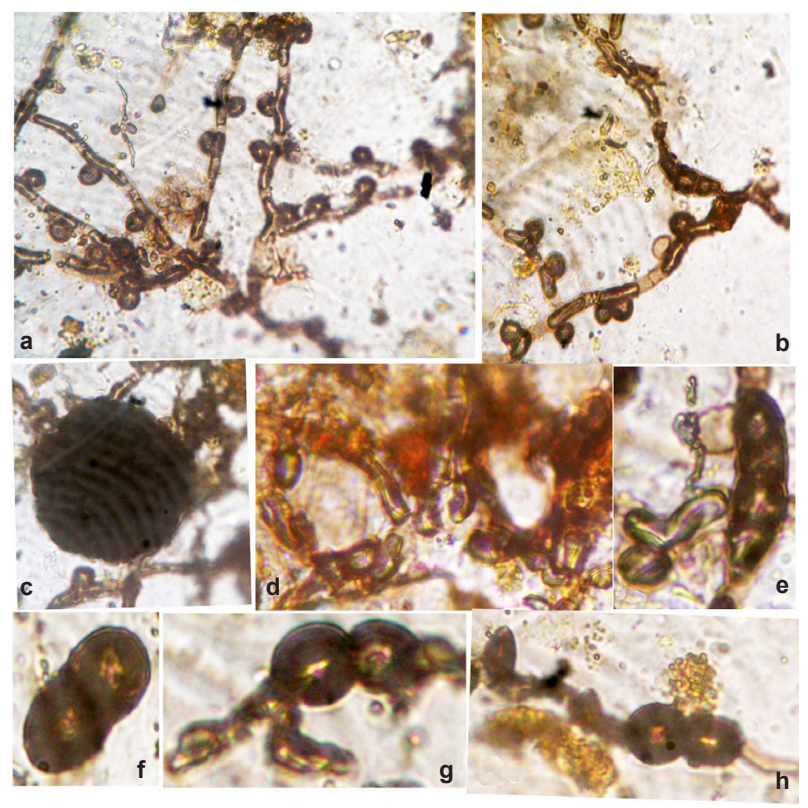

Image 4. Schiffnerula hoddurensis sp. nov.

a - Appressoriate mycelium; $b$ - Colony formed from the Questieriella conidia; c - Initial state of thyriothecium; d - Totally opened thyriothecium with the remnants of marginal cells; e - Germinating Questieriella conidia; f - Ascospore; g-h - Germinating ascospores 
unilateralis vel alternata, raro opposita, unicellularis, globosa, mammiformes, crassa posita, integra, raro angularis, 5-10 x 6-11 $\mu \mathrm{m}$. Conidia Questieriella pauca, dispersa, 3-septata, leniter constrictus ad septata, recta vel curvula, attenuatae ad ambi apicem, cellulae terminalis acutae vel subacutae, 17-36 x 8-10 $\mu \mathrm{m}$. Thyriothecia dispersa, orbicularis, nigra ad initio, portionio centralis dissolutus ad maturitatus; asci globosi vel ovati, 15-18 $\mu \mathrm{m}$ diam.; ascosporae brunneae, conglobatae, uniseptatae, 23-26 x 11-13 $\mu \mathrm{m}$.

Colonies epiphyllous, dense, up to $7 \mathrm{~mm}$ in diameter. Hyphae flexuous, branching subopposite to alternate at acute to subacute angles, closely to loosely reticulate, cells $23-28$ x 4-6 $\mu \mathrm{m}$. Appressoria scattered, unilateral to alternate, rarely opposite, unicellular, globose, mammiform, broad based, entire, rarely angular, 5-10 x 6-11 $\mu \mathrm{m}$. Questieriella conidia few, scattered, 3-septate, slightly constricted at the septa, straight to curved, taper towards both ends, end cells acute to subacute, $17-36 \times 8-10 \mu \mathrm{m}$. Thyriothecia scattered, orbicular, initially charcoal black, central portion dissolved at the centre at maturity; asci globose to ovate, $15-18 \mu \mathrm{m}$ in dia.; ascospores brown, conglobate, uniseptate, $23-26 \times 11-13 \mu \mathrm{m}$.

Sarcinella jabalpurensis R.C. Rajak \& Soni is known on this host from Jabalpur, Madhya Pradesh (Rajak \& Soni 1981). Since the Sarcinella state is not known in the present collection, it is not worth to state that both the taxa are the same. Hence, the present collection has been placed under a new species of its teleomorph.

This species was associated with Asteridiella depokensis.

Etyomology: The species is named after its collection locality.

\section{REFERENCES}

Hosagoudar, V.B. (2003). The genus Schiffnerula and its synanamorphs. Zoos' Print Journal 18(4): 1071-1078.

Hosagoudar, V.B. (2011). The genus Schiffnerula in India. Plant Pathology \& Quarantine 1(2): 131-204.

Hosagoudar, V.B. \& A. Sabeena (2010). New and less known fungi from Kerala, India. Taiwania 55(3): 249-253.

Rajak, R.C. \& K.K. Soni (1981). Foliicolous ectoparasites from Jabalpur-I. Some Sarcinellae. Indian Journal of Mycology \& Plant Pathology 11: 89-91. 